\title{
Public Health Implication of Microbial Loads in Smoked Mackerel, Scomber scombrus from Major Fish Markets in Uyo, Akwa Ibom State, Nigeria
}

\author{
Mmandu U. Effiong ${ }^{*}$, Esther U. Christopher \\ Department of Animal and Environmental Biology, University of Uyo, Akwa Ibom State, Nigeria \\ *Corresponding Author \\ Mmandu U. Effiong
}

\author{
Article History \\ Received: 09.07.2020 \\ Accepted: 17.07 .2020 \\ Published: 29.07.2020
}

\begin{abstract}
As a way of checkmating public health implication associated with processed fish products, the study was conducted to assess the bacterial load and diversity in the fillets of smoked Atlantic mackerel, Scomber scombrus sold in major fish markets (Anua, Useh, Etuk, Itam and Akpan-Andem) in Uyo, Akwa Ibom State. Determination of bacterial loads, species characterization and composition in fish fillets were done using standard microbiological procedures. Results from the study revealed the highest fungal counts of $9.0 \times 10^{4} \mathrm{cfu} / \mathrm{ml}$ in samples from Itam market. Heterotrophic bacteria count ranged from $2.0 \times 10^{6} \mathrm{cfu} / \mathrm{ml}$ in Useh market samples to $2.5 \times 10^{6} \mathrm{cfu} / \mathrm{ml}$ in samples from other study sites. A total of eleven bacterial and six fungal species were recovered. Salmonella enterica and Shigella sonnei accounted for the highest frequency of occurrence (100\%) in all the study sites while Escherichia coli and Vibro cholera had $80 \%$ prevalence. Serratia liquenfaciens, Bacillus subtilis, Lactobacillus plantarum, Micrococcus luteus and Bacillus cereus recorded $40 \%$ occurrence while the least prevalence of $20 \%$ was recorded in Staphylococcus albus and Proteus mirabilis. The isolated fungal species were Penicillum expansum (60\% prevalence), Aspergillus flavus, Mucor hiemalis, Rhizopus stolonifer and Geotriculun candidum (40\%) while A. fumigates (20\%). Bacterial flora recovered in this study composed of potential pathogenic organisms of public health interest. This calls for intensified monitoring efforts towards controlling fish food contamination in Uyo metropolis.
\end{abstract}

Keywords: Atlantic mackerel, bacterial load, diversity, fungal species, contamination.

\section{INTRODUTION}

Fish and fishery products are important food components for humans with an estimated consumption level of about $20.1 \mathrm{~kg}$ per capita FAO [1]. In developing countries such as Nigeria, fish products are accessible and relatively affordable. They are presented in several forms such as fresh, dried, smoked, frozen and canned. In Nigeria, preservation of fresh fish remains a problem due to lack of adequate infrastructures Anihouvi, et al, [2]. Thus, in order to prevent fish spoilage and post-harvest losses, various preservation methods such frying, drying, fermentation, salting and smoking are employed Ikutegbe and Sikoki [3]. Traditional fish smoking is however the main method used by fisher folks in preserving mackerel fish in Uyo. Smoking involves subjecting fish to direct or indirect action of heat which dries and preserve it from spoilage Koffi [4]. The Atlantic mackerel (Scomber scombrus) is the most important pelagic fish that is generally consumed in Uyo. It is also the most abundant and widely distributed migratory fish species in Nigeria. The fish is commonly seen either in fresh or smoked form in most open markets in the study area. These products are displayed on trays in selling points thus exposing them to several contaminating agents.

The presence of bacteria in fish could play diverse roles, some of which might be beneficial to the fish Egerton et al. [5]; Butt and Volkoff [6]. On the other hand, the presence of some bacterial species could lead to post harvest spoilage and adverse health conditions in farmed fishes Effiong and Isaac [7]. Fish and fish products are susceptible to a wide variety of bacterial and fungal invasion due to poor processing and handling methods. If allowed to proliferate, these microbes can change the physical and chemical nature of the fish leading to spoilage, food poisoning and food borne infections. In addition, these microbes had been reported to be major agents associated with diseases in human Guarner and Malagelada [8] and are known to be closely associated with the physiological status and postharvest quality

Copyright @ 2020: This is an open-access article distributed under the terms of the Creative Commons Attribution license which permits unrestricted use, distribution, and reproduction in any medium for non commercial use (NonCommercial, or CC-BY-NC) provided the original author and source are credited. 
of fish Al-Harbi and Uddin [9]. Earlier study by Feldhusen [10] stated that microbes are capable of causing diseases by passing infection to the host. Thus, these microflorae may be significant in fish spoilage as well as being able to transmit many of the established food borne microbial infections and intoxications. For instance, some of the isolated species like Bacillus and Staphylococcus had been noted to cause serious diseases in farmed fish Amande and Nwaka [11]; Effiong and Isaac [7] while others like Pseudomonas and Escherichia coli had been implicated in zoonosis to humans Babu [12]; Edun et al. [13]. Fish is the main source of protein for the people living in Uyo, Akwa Ibom State, and given the prevalence of water and food borne diseases in the area, it is in order that all possible infection routes of pathogens be investigated and possible mitigation measures outlined. On this note, the present study was designed to evaluate bacterial load and species diversity in the fillets of smoked Atlantic mackerel from major fish markets in Uyo.

\section{Materials ANd Methods Collection of Experimental Fish}

The experimental fish were procured from five major fish markets (Anua, Useh, Etuk, Itam and Akpan-andem) in Uyo, Akwa Ibom State, Nigeria. A total of 100 specimen of smoked mackerel were collected (20 samples from each market) and used for the study. Samples were transported to the laboratory of the Department of Microbiology, University of Uyo, for detailed examination and analysis.

\section{Sample Preparation, Culture and Bacterial Isolation}

The study considered fish fillets for examination for possible presence of microbial agents. Samples from each market were separately made into fine particles using a manual blender. A $10 \mathrm{~g}$ from each sample was homogenized with $90 \mathrm{ml}$ of sterile water and the homogenate was allowed to settle for 10 minute. Thereafter, $5 \mathrm{ml}$ of the supernatant was transferred to make a 10 -fold serial dilution. One $\mathrm{ml}$ of the diluted sample was inoculated using pour plate technique and a $0.5 \%$ Nutrient agar medium was poured at $40^{\circ} \mathrm{C}$ on the plates. The sample and the medium were then mixed and allowed to set before incubating at $25^{\circ} \mathrm{C}$ for 48 hours. Colonies were sub-cultured to get pure cultures. These were further screened for the presence of indicator organisms. Microbial assay of the fillets was carried out to determine bacterial load, identification and frequency of occurrence using the method described by Cheesbrough [14]. Plates with colonies ranging between 50 - 200 were selected for determination of total bacterial count and isolation of individual bacterial groups. Total load of bacteria was estimated thus: Total load of bacteria $(\mathrm{cfu} / \mathrm{ml})=\mathrm{C} \times \mathrm{D} \times 10 \times \mathrm{V} / \mathrm{W}$ Cheesbrough [14] where: $\mathrm{C}=$ Number of colonies found, $\mathrm{D}=$ Dilution factor, $\mathrm{V}=$ Volume of physiological saline, $\mathrm{W}=$ Weight of fish sample.

\section{Characterization of Bacteria/Fungal Identification}

Fungal isolates were identified by cultural and morphological characteristics which include surface texture, topography and pigmentation as described by Akintobi et al. [15]. Microscopic identification was done by placing a drop of $5 \%$ potassium manganese $(\mathrm{kMnO} 4)$ on a slide and a small portion of representative fungi mycelium was removed and teased onto the potassium manganese stain using a sterile needle. The slide was covered, mounted and then viewed at 10x and 40x objective microscope Mailafia et al. [16]. Photos of identified fungal isolates were taken and compared with a documented book of fungi St-Germain and Summerbell [17].

Visual observation of morphological characteristics such as shape, size and color of the bacterial colonies were done. Shape of the individual isolate was determined by Gram staining method with the young culture. The motility test was performed by hanging drop method. Biochemical tests such as catalase activity, oxidase, indole production, gelatin liquefaction and proteinase test were performed using bacterial isolates from fresh culture according to the methods of Barrow and Feltham [18]. The pure fungal isolates were identified using both cultural and morphological characteristic texture (glabrous, powdery, granular, fluffy, downy, cottony,) surface topography (flat, raised, heaped, folded, domed, radial, grooved) surface pigmentation (white, creamy, yellow, brown, pink, grey, black) reverse pigmentation (yellow, none, brown, red, black) according to the general method by Akintobi et al. [15]. The procedure involved visual examination of isolates in culture (pigmentation, texture, reverse side, colony surface) and observation of stain preparation (nature of conidia, hyphae and spores) under microscope.

\section{Data Analysis}

Data collected for microbial counts were subjected to descriptive statistics and differences in species load and diversity were analyzed using one-way analysis of variance (ANOVA) at 95\% probability level using SPSS version 20. The bacterial and fungal isolates were presented in tables.

\section{RESULTS}

The results of bacterial counts in fillets of smoked mackerel are presented in Table 1. Total heterotrophic bacterial count ranged between $2.0 \times 10^{6} \mathrm{cfu} / \mathrm{ml}$ in Useh market samples and $2.5 \times 10^{6} \mathrm{cfu} / \mathrm{ml}$ in samples from all other 
markets. The least fungal count of $1.0 \times 10^{4} \mathrm{cfu} / \mathrm{ml}$ was recorded in samples from Useh market while the highest $(9.0 \mathrm{x}$ $10^{4} \mathrm{cfu} / \mathrm{ml}$ ) was obtained in Itam samples. There was no Pseudomonas count in all the samples examined. Table 2 showed the primary characterization of different bacterial isolates. From the results, the entire bacterial flora showed negative to coagulase and haemolysis tests. The microbes were dominated by gram - negative rod shaped organisms. The results of biochemical tests for the different bacterial isolates are presented in Table 3. Here, all the bacterial species were positive to proteinase test. In all other tests, organisms showed different responses. The results of macroscopic and microscopic identification of fungal isolates are shown in Table 4. The results in Table 5 indicated that Salmonella enterica and Shigella sonnei accounted for the highest frequency of occurrence (100\%). These organisms were observed in all the market samples. Staphylococcus albus and Proteus mirabilis had the least prevalence of $20 \%$ occurring only in Itam and Anua markets respectively. Among the fungal isolates, Penicillium expansum had the highest prevalence (60\%) while Aspergillus fumigatus had the least value of $20 \%$.

Table-1: Microbial densities in smoked mackerel from major fish markets in Uyo

\begin{tabular}{|l|l|l|l|l|l|}
\hline Bacterial counts & Anua & Useh & Etuk & Itam & Akpan-andem \\
\hline THBC $(\mathrm{cfu} / \mathrm{ml})$ & $2.5 \times 10^{6}$ & $2.0 \times 10^{6}$ & $2.5 \times 10^{6}$ & $2.5 \times 10^{6}$ & $2.5 \times 10^{6}$ \\
\hline TFC $(\mathrm{cfu} / \mathrm{ml})$ & $2.0 \times 10^{4}$ & $1.0 \times 10^{4}$ & $6.0 \times 10^{4}$ & $9.0 \times 10^{4}$ & $7.0 \times 10^{4}$ \\
\hline FCC $(\mathrm{cfu} / \mathrm{ml})$ & $8.7 \times 10^{5}$ & $3.0 \times 10^{5}$ & $1.7 \times 10^{5}$ & $1.2 \times 10^{5}$ & $1.4 \times 10^{5}$ \\
\hline TCC $(\mathrm{cfu} / \mathrm{ml})$ & $1.98 \times 10^{6}$ & $9.2 \times 10^{5}$ & $2.3 \times 10^{6}$ & $1.2 \times 10^{6}$ & $1.06 \times 10^{6}$ \\
\hline SSC $(\mathrm{cfu} / \mathrm{ml})$ & $1.84 \times 10^{6}$ & $1.5 \times 10^{5}$ & $2.0 \times 10^{6}$ & $6.1 \times 10^{5}$ & $1.1 \times 10^{5}$ \\
\hline TVC $(\mathrm{cfu} / \mathrm{ml})$ & $7.6 \times 10^{5}$ & $1.3 \times 10^{5}$ & $1.9 \times 10^{5}$ & $1.4 \times 10^{5}$ & $1.8 \times 10^{5}$ \\
\hline SC $(\mathrm{cfu} / \mathrm{ml})$ & $1.0 \times 10^{5}$ & $7.0 \times 10^{5}$ & $1.1 \times 10^{6}$ & $2.9 \times 10^{5}$ & $4.9 \times 10^{5}$ \\
\hline PC & - & - & - & - & - \\
\hline
\end{tabular}

Where: THBC: Total heterotrophic bacterial counts; TFC; Total fungal count FCC: Faecal coliform count; TCC: Total coliformcount: SSC: Salmonella shigella count; TVC: Total vibro count; SC: Staphylococcus count; PC: Pseudomonas count

Table-2: Primary characterization of different bacterial isolates in smoked mackerel from major fish markets in

\begin{tabular}{|l|l|l|l|l|l|l|l|l|l|l|l|}
\hline Characters & A & B & C & D & E & F & G & H & I & J & K \\
\hline Gram stain & - & - & - & - & - & + & + & + & + & - & - \\
\hline Shape & R & R & R & R & comma & cocci & R & R & cocci & R & R \\
\hline Motility & + & + & + & + & + & - & + & - & - & + & + \\
\hline Catalase & + & + & + & + & + & + & + & - & + & + & + \\
\hline Coagulase & - & - & - & - & - & - & - & - & - & - & - \\
\hline Starch & + & - & - & - & + & - & + & - & + & - & + \\
\hline Urease & - & - & - & - & - & - & + & + & + & + & - \\
\hline Oxidase & - & - & + & - & - & - & - & - & - & - & - \\
\hline Citrate & + & - & + & - & + & + & - & - & + & - & - \\
\hline Haemolysis & - & - & - & - & - & - & - & - & - & - & - \\
\hline Lipase & - & - & - & - & - & - & - & - & - & + & - \\
\hline Glucose & - & AG & A & A & A & A & AG & A & A & AG & AG \\
\hline Maltose & AG & AG & A & AG & A & A & A & A & A & A & A \\
\hline Fructose & - & - & - & - & A & AG & A & A & A & AG & A \\
\hline Sucrose & - & - & - & AG & AG & - & - & - & - & AG & A \\
\hline Mannitol & AG & AG & AG & AG & A & AG & - & - & A & - & - \\
\hline Galactose & A & - & - & A & A & A & A & AG & A & AG & A \\
\hline
\end{tabular}

Where: A: Serratia; B: Escherichia; C: Salmonella; D: Shingella; E: Vibrio; F: Staphylococcus; G: Bacillus subtilis; H:

Lactobacillus; I: Micrococcus; J: Proteus; K: Bacillus aureus; R; Rod; -: Negative; +: Positive; A: acid; AG: Acid and Gas

Table-3: Results of the biochemical tests for the bacterial isolates

\begin{tabular}{|l|c|c|c|c|c|c|c|c|c|c|c|}
\hline & \multicolumn{1}{|c|}{ Response by different bacterial isolates } \\
\hline Characters & A & B & C & D & E & F & G & H & I & J & K \\
\hline Indole production & - & + & - & - & - & + & - & - & - & + & - \\
\hline Proteinase test & + & + & + & + & + & + & + & + & + & + & + \\
\hline Citrate utilization test & + & - & + & - & + & + & + & + & - & - & - \\
\hline $\mathrm{H}_{2}$ S production test & + & - & + & - & - & - & - & - & - & + & - \\
\hline Gelatin liquefaction & - & - & + & - & - & - & - & - & - & - & + \\
\hline
\end{tabular}

Where: A: Serratia; B: Escherichia; C: Salmonella; D: Shingella; E: Vibrio; F: Staphylococcus; G: Bacillus subtilis; H: Lactobacillus; I: Micrococcus; J: Proteus; K: Bacillus aureus; -: Negative; +: Positive. 
Table-4: Macroscopic and microscopic examination of fungal isolates from smoked fish samples

\begin{tabular}{|l|l|l|}
\hline Macroscopic & Microscopic & Inference \\
\hline $\begin{array}{l}\text { Front black with white reverse side, filamentous soma and } \\
\text { dense felt yellow-green } \\
\text { Colony }\end{array}$ & Unbranched aseptate hyphae & Aspergillus sp \\
\hline $\begin{array}{l}\text { Front white with creamy reverse side, filamentous soma and } \\
\text { grayish yellow colony }\end{array}$ & $\begin{array}{l}\text { Branched aseptate coenocytic } \\
\text { hyphae }\end{array}$ & Mucor hiemalis \\
\hline $\begin{array}{l}\text { Front brown with wooly reverse side, filamentous soma and } \\
\text { blue-green colony }\end{array}$ & $\begin{array}{l}\text { A 3-stage branched } \\
\text { Conidiosphores }\end{array}$ & $\begin{array}{l}\text { Penicillium } \\
\text { expansum }\end{array}$ \\
\hline $\begin{array}{l}\text { Front white with cotton reverse side, filamentous soma and } \\
\text { membranous colony }\end{array}$ & $\begin{array}{l}\text { Branched aseptate and very } \\
\text { narrow hyphae }\end{array}$ & $\begin{array}{l}\text { Rhizopus } \\
\text { stolonifera }\end{array}$ \\
\hline $\begin{array}{l}\text { Front blue with white reverse side filamentous soma and white } \\
\text { becoming membranous colony }\end{array}$ & $\begin{array}{l}\text { Dichotomously branched septate } \\
\text { hyphae }\end{array}$ & $\begin{array}{l}\text { Geotriculum } \\
\text { candidum }\end{array}$ \\
\hline
\end{tabular}

Table-5: Prevalence of occurrence of bacterial and fungal isolates from pooled smoked fish samples

\begin{tabular}{|l|c|l|c|}
\hline Bacterial Isolates & \% Prevalence & Fungal isolates & \% Prevalence \\
\hline Serratia liquefaciens & 40 & Aspergillus flavus & 40 \\
\hline Escherichia coli & 80 & Mucor hiemalis & 40 \\
\hline Salmonella enterica & 100 & Penicillium expansum & 60 \\
\hline Shigella sonnei & 100 & Rhizopus stolonifera & 40 \\
\hline Vibro cholera & 80 & Geotriculum candidum & 40 \\
\hline Staphylococcus albus & 20 & Aspergillus fumigatus & 20 \\
\hline Bacillus subtilis & 40 & & \\
\hline Lactobacillus plantarum & 40 & & \\
\hline Micrococcus luteus & 40 & & \\
\hline Proteus mirabilis & 20 & & \\
\hline Bacillus cereus & 40 & & \\
\hline
\end{tabular}

\section{DISCUSSION}

Fish being low in fat and high in protein contents play significant roles in the diets of both man and livestock. Examining factors that may contribute to their spoilage becomes necessary. Fish parasites (bacteria, fungi, virus, etc) had been reported to cause about $45 \%$ loss in fish farms Kabata [19]. Study by Cheesbrough [20] showed that serious disease outbreak had occurred in both human and animals after consuming contaminated fish. This could have been as a result of the presence of disease causing organisms such as Escherichia coli, Salmonella typhi, and Vibro cholera. The contamination usually occurs as a result of improper handling and indecent processing practices of ready-to-eat fish products. The present study showed that pathogenic bacterial and fungal species were present in all smoked mackerel samples collected from Anua, Itam, Etuk, Akpanandem and Uśeh markets in Uyo, Akwa Ibom State. A total of 11 bacterial (Serratia liquefaciens, Escherichia coli, Salmonella enterica, Shigella sonnei, Vibro cholera, Staphylococcus albus, Bacillus subtilis, Lactobacillus plantarum, Micrococcus luteus, Proteus mirabilis and Bacillus cereus) and 6 fungal (Aspergillus flavus, Mucor hiemalis, Penicillium expansum, Rhizopus stolonifera, Geotriculum candidum and Aspergillus fumigatus) species were isolated. Similar organisms were severally reported from street vended and open markets processed fish samples by Amusan et al. [21] in Street vended smoked blue whiting (Micromesistus poutasou); Nyarko et al. [22] in smoked sardine (Sardinella aurita) at smoking sites and market centre of Tema, Ghana; Yusuf and Hamid [23] in smoked Clarias gariepinus retailed in Bauchi metropolis, Nigeria; Adebayo-Tayo et al. [24] in fresh marine catfish (Arius hendelotic) from different markets in Akwa Ibom State, Nigeria; Adegunwa et al. [25] in smoked herring (Sardinella eba) from Ogun State, Nigeria; Ibrahim et al. [26] in smoked Clarias gariepinus in Minna, Nigeria.

Bacterial species had been widely reported as predominant organisms that contaminate smoked fish leading to spoilage Adegoke [27]; Yusuf and Hamid [23]; Adelaja et al. [28]. The route of contamination had always been poor sanitary condition and lack of adequate packaging of products since they are always seen exposed at the open markets. Herman et al. [29] opined that Staphylococcus species constitute the normal flora causing human skin and mucous membrane diseases. The species E. coli and Salmonella sp are known to be faecal borne pathogens which could occur in fish food as a result of contamination from handlers or polluted culture water. Alexander and Austin [30] earlier reported that fish harvested from contaminated water can harbor Salmonella sp. and other pathogenic microbes. These organisms which were dominant in all fish samples examined in this study had been linked to several health hazards in humans. For instance, Adelaja et al. [28] reported that E. coli caused diarrhea and kidney damage, as well as complicated community acquired urinary tract infection in human while Salmonella sp caused gastroenteritis and typhoid fever. The presence of Aspergellus flavus and A. fumigatus in smoked mackerel marketed in Uyo is of great health concern because of their mycotoxigenic potentials. The reports of Essien et al. [31] showed that A. flavus and A. fumigatus produced aflatoxins, 
which are capable of destroying both liver and kidney in man. Other fungal species such as Muccor sp, Rhizopus stolonifer and Geotriculun candidum had been reported to be detrimental to human health Iwamoto et al. [32]. The consumption of contaminated fish could therefore cause serious health issues in man. According to Hosein et al. [33], seafood contributes a burden of disease to man since they are capable of transmitting many of the established food borne microbial infections and intoxications. The results of this study showed a high contamination level. Thus, smoking could be classified as a mild preservative treatment which may not achieve complete elimination of microbial load of fresh fish. Thus smoked fish should be properly cooked before consumption. Therefore, the presence of all the aforementioned pathogenic organisms in smoked Scomber scombrus in this study is an indication that the hygiene and safety condition of smoked fish is compromised.

\section{CONCLUSION}

The study revealed the presence of some bacterial and fungal species in all smoked mackerel samples collected from the five different fish markets in Uyo, Akwa Ibom State. Some of the recovered species composed of potential pathogenic organisms of public health interest. The presence of these organisms may have been through improper handling of fish and fish products. Therefore, it is noteworthy that sanitary condition under which fishes are handled, processed and stored be improved upon to ensure standard and safe fish food products for consumers.

\section{ACKNOWLEDGMENTS}

The authors sincerely appreciate the kindness of Dr Naomi Asamudo, the Head of the Department of Microbiology, University of Uyo for allowing us use their laboratory equipment for the research.

\section{REFERENCE}

1. FAO. (2016). Food and Agriculture Organization of the United States. The state of world's fisheries and aquaculture. Retrieved from http://www.fao.org/publications/ofia/2016/en.

2. Anihouvi, V., Kinclossi, I., \& Hounhouigen, J. (2012). Processing and quality characteristics of some major fermented fish products from Africa: A critical review. International Research Journal of Biological Sciences, 1: $72-$ 84.

3. Ikutegbe, V., \& Sikoki, F. (2014). Microbiological spoilage of smoke dried fishes sold in West African open markets. Food Chemistry, 161: 332-336.

4. Koffi, A. G. (2007). Quality Assurance in Fishing Industry. Scientific and Technical Handbooks, Actes Edition, 72.

5. Egerton, S., Culloty, S., Whooley, J., Stanton, C. \& Ross, R. P. (2018). The gut microbiota of marine fish. Frontiers in Microbiology, 9: 873.

6. Butt, R. L., \& Volkoff, H. (2019). Gut microbiota and energy homeostasis in fish. Frontiers in Endocrinology, $10: 9$.

7. Effiong, M. U., \& Isaac, I. N. (2019). Comparative Study of the Bacterial Load and Species Diversity in the African Catfish (Clarias gariepinus) Cultured in Contrasting Aquaculture Tanks in Uyo, Nigeria, Animal Research International, 16(3): 3443 - 3449.

8. Guarner, F., \& Malagelada, J. R. (2003). Gut flora in health and disease. The Lancet, 361(9): 512 - 519.

9. Al-Harbi, A. H., \& Uddin, N. (2003). Quantitative and qualitative studies on the bacterial flora of hybrid Oreochromis niloticus x O. aureus cultured in earthen ponds in Saudi Arabia. Aquaculture Research, $34(1): 43$ - 48.

10. Feldhusen, F. (2000). The role of seafood in bacterial foodborne diseases. Microbes and Infection, 2(13): 1651 1660 .

11. Amande, T. J., \& Nwaka, S. U. (2013). Bacterial flora of African catfish (Clarias gariepinus) harvested from ponds in Uyo South-South Nigeria. IOSR Journal of Environmental Science, Toxicology and Food Technology, 5(3): 72 76.

12. Babu, P. S. (2000). Ichyozoonoses. Fish Farmer International, 14: $14-17$.

13. Edun, O. M., Akunsotimi, O., Opara, J. Y., Owhonda, K.N., Onunkwo, D.N. \& Anyanwu, P. E. (2007). Public health and economic implication of the microbial floral of cultivable fresh water fishes. Journal of Fisheries International, 2(4): 274-276.

14. Cheesbrough, M. (2000). District Laboratory Practice in Tropical Countries Part 2. Cambridge University Press, United Kingdom.

15. Akintobi, A. O., Okonko, I. O., Agunbiade, S. O., Akano, O. R. \& Onianwa, O. (2011). Isolation and identification of fungi associated with the spoilage of some selected fruits in Ibadan South western Nigeria. Academia Arena, 3(11): 1-10.

16. Mailafia, S., Okoh, G. R., Olabode, H. O. K., \& Osanupin, R. (2017). Isolation and identification of fungi associated with spoilt fruits vended in Gwagwalada market, Abuja, Nigeria. Veterinary World, 10(4): 393-397.

17. St-Germain, G., \& Summerbell, R. (2003). Identifying filamentous fungi. A clinical laboratory handbook. Belmont, Star Publishing, 314p. 
18. Barrow, G. I., \& Feltham, R. K. A. (1993). Cowan and Steel's Manual for the Identification of Medical Bacteria. 3rd Edition, Cambridge University Press, Cambridge, United Kingdom.

19. Kabata, Z. (2008). Parasites and diseases of fish in the tropics, Taylor Francis publication, London, 92

20. Cheesbrough, M. (2002). Biochemical tests to identify bacteria. In; Laboratory practices in tropical countries, Cambridge Edition, pp 36-70.

21. Amusan, E., Oramadike, C. E., Abraham-Olukayode, A. O., \& Adejonwo O. A. (2010). Bacteriological quality of street vended smoked blue whiting (Micromesistus poutasou). Internet Journal of Food Safety, 12:122-126.

22. Nyarko, H. D., Obodai, E. A., Boamponsem, L. K. Coomson, S. S. \& Aniwe, Y. (2011). Microbial profile of smoked sardine (Sardilella aurita) at smoking sites and market centres of Tema, Ghana. Appl. Sci. Res, 3(3): $443-453$.

23. Yusuf, M. O., \& Hamid, T. A. (2012). Isolation and identification of bacteria in retailed smoked fish within Bauchi metropolis. IOSR Journal of Pharmacy and Biological Sciences, 3(1): 1-5.

24. Adebayo-Tayo, B. C., Odu, N. N., Igiwiloh, N. J. P. \& Okonko, I. O. (2012). Microbiological and physicochemical level of fresh catfish (Arius hendelotic) from different markets in Akwa Ibom State, Nigeria. New York Science Journal, 5(4): 46-52.

25. Adegunwa, M. O., Adebowale, A. A., Olisa, Z. G. \& Bakare, H. A. (2013). Chemical and microbiological qualities of smoked herring (Sardinella eba, Valenciennes 1846) in Odeda, Ogun State, Nigeria. International Journal of Microbiological Research, 1(5): $85-87$.

26. Ibrahim, B. U., Baba, J., \& Sheshi, M. S. (2014). Isolation and identification of bacteria associated with fresh and smoked Clarias gariepinus in Minna metropolis, Niger State, Nigeria Journal of Applied Environmental Microbiology, 2(3):81 - 85 .

27. Adegoke, G. O. (2004). Understanding Food Microbiology, $2^{\text {nd }}$ Edition, $173-174$.

28. Adelaja, O. O., Olalekan, J., Ikenweiwe, N. B., \& Ashley-Dejo, S. S. (2013). Comparison of microbial load associated with smoked fish (Chrysichthys nigrodigitatus) from Oyan Lake and Ogun Waterside in Ogun State, Nigeria. Global Journal of Science Frontier Research Agriculture and Veterinary, 13(8)1: 35-39.

29. Herman, H. H., Lin, W., Petrecca, P. J., Simmons, M. R., \& Houghton, J. (2011). Centrifugal Bioreactors and their application in remediation. Remediation Journal, 11(4): 15-33.

30. Alexander, B., \& Austin, B. (1986). Bacterial microflora associated with a commercial fish smoker. FEMS Microbiology Letters, 3493): 309-312.

31. Essien, J. P., M. Ekpo, A., \& Brooks, A. A. (2005). Mycotoxigenic and proteolytic potential of moulds associated with smoked shark fish (Chlamydoselachus anguincus). Journal of Applied Science Environmental Management, 9: 53-57.

32. Iwamoto, M., Ayers, T., Mahon, B. E. \& Swerdlow, D. L. (2010). Epidemiology of seafood-associated infections in the United States. Clinical Microbiology Reviews, 23(2): 399-411.

33. Hosein, A., Munoz, K., Sawh, K. \& Adesiyum, A. (2008). Microbial load and the prevalence of E. coli, S. sp. and Listeria sp. in ready-to-eat products in Trinidad. The Open Food Science Journal, 2: 23-28. 